\title{
Systemic Therapy in Patients with Resectable and Unresectable Cases of Giant Cell Tumor: A Systematic Review
}

\author{
Philip B. Kaiser, Jocelyn T. Compton, Jon-Michael E. Caldwell, Thomas R. Hickernell, \\ Francis Y. Lee ${ }^{*}$ \\ Department of Orthopaedic Surgery, New York Presbyterian Hospital Columbia University, New York, USA \\ Email: ${ }^{\text {fl}} 127 @$ columbia.edu
}

Received 23 January 2014; revised 20 February 2014; accepted 27 February 2014

Copyright (C) 2014 by authors and Scientific Research Publishing Inc.

This work is licensed under the Creative Commons Attribution International License (CC BY). http://creativecommons.org/licenses/by/4.0/

\section{Abstract}

Background: Giant cell tumor (GCT) is a common benign tumor of the appendicular and axial skeleton that represents $5 \%$ of all primary bone tumors. In recent years, the combination of conventional aggressive curettage with targeted adjuvant anti-osteoclastic agents including bisphosphonates and denosumab have led to lower recurrence rates in patients with GCT in a small number of retrospective case series. Furthermore, efficacy of the same anti-osteoclastic agents has been shown in cases of unresectable GCT of bone, leading to decreased rates of tumor progression and stabilization of disease. This review assesses whether the current literature weakly, moderately, or strongly supports a targeted systemic treatment as the standard of care in patients with GCT. Methods: We conducted a current search of the MEDLINE database for literature pertaining to systemic GCT treatment. Our inclusion criteria were as follows: 1) studies that reported on a series of patients with resectable or unresectable cases of GCT; 2) a subset of patients must have been treated with systemic bisphosphonate or RANK-L inhibitor therapy; 3) each series had a minimum of 10 patients with histopathologically confirmed GCT; 4) each series stated their follow-up period. Results: Overall 6 studies, reporting on a total of 487 patients, were selected for inclusion in this review. For analysis, these 6 retrospective studies were subdivided into series where all GCT patients had resectable tumors $(n=4)$ and series where patients had a mix of resectable and unresectable tumors $(n=2)$. The overall recurrence rate of GCT in patients with resectable tumors treated with adjuvant systemic bisphosphonates was $6.7 \%$ compared to $48.4 \%$ in patients not treated with adjuvant systemic bisphosphonates $(p<0.0001)$. In patients with both resectable and unresectable primary aggressive, recurrent, or metastatic GCT disease, systemic bisphosphonate and denosumab demonstrated good efficacy with decreased rates of disease progression and recurrence. In general the side effects of bisphosphonates were mild while denosu-

${ }^{*}$ Corresponding author. 
mab had a more severe side effect profile. Conclusions: Systemic treatment with bisphosphonates or denosumab in cases of GCT is promising, but there is a lack of high-level evidence with sufficient follow-up supporting their use. We believe the current literature provides moderate support to recommend a short course of adjuvant peri-operative systemic bisphosphonate treatment for patients with resectable primary GCT and moderate support to recommend adjuvant peri-operative (resectable) and non-operative (unresectable) use of denosumab in cases of primary aggressive, recurrent, or metastatic GCT. With either systemic treatment, patients should be well counseled on all potential side effects in addition to alternative treatment, which includes the option of no systemic treatment.

\section{Keywords}

Giant Cell Tumor, Systemic Therapy, Bisphosphonates, Denosumab

\section{Introduction}

Giant cell tumor (GCT) is a benign tumor of the appendicular or axial skeleton that accounts for approximately $5 \%$ of all primary bone tumors, typically occurring in patients aged 20 through 40 years with a slight female predominance [1] [2]. Histologically GCT is comprised of 3 cell types: 1) multinucleated osteoclast-like giant cells; 2) fibroblast-like spindle-shaped (GCT stromal) cells, which represent the neoplastic component of GCT and overproduce ligand for receptor activator of NF-kappa B (RANKL); and 3) mononuclear cells that comprise osteoclast precursor cells [3] [4]-[6].

While GCT of bone is a benign neoplasm, it has a propensity for aggressive local invasion and destruction with an overall recurrence rate as high as $75 \%$ when managed by simple curettage alone [1] [2] [7]. The most common locations of GCT include epiphyseal ends of the distal femur, proximal tibia, and distal radius often adjacent to the joint surface; however, GCT can also be located in the sacrum or mobile spine [1] [3] [4]. Metastases are rare in GCT, occurring in only $2 \%-3 \%$ of all patients, and are most commonly found in the lung. On radiographs, GCT demonstrates an osteolytic bone destruction pattern, which may be confined to a small area within the bone (stage I), expand the cortex (stage II), or breach the cortex and extend into the soft tissues (stage III) [4].

Aggressive surgical resection and reconstruction is associated with a low incidence of tumor recurrence: however, joint mobility and functionality may be significantly reduced and long term outcomes of en bloc resection are generally poor [2]. Advancement from simple curettage to aggressive curettage involves the use of a high-speed burr at the tumor-bone interface and chemical agents such as alcohols and thermogenic bone cement within the tumor cavity may enhance marginal excision [2]. High-speed burr use and bone cement filling are both independent factors leading to lower recurrence rates in the surgical treatment of GCT [2] [8] [9]. The current standard of care for resectable GCT, utilizing high-speed burr curettage of the tumor cavity and thermogenic bone cement packing, has led to overall recurrence rates in the literature from $10 \%$ to $50 \%$, with some of the variation attributable to tumor location, tumor aggression, and surgical technique [4] [10]. In a study published in 1982 in the American edition of Journal of Bone and Joint Surgery, Sung et al. followed 111 patients with histologically proven GCT and found an overall recurrence of 26.1\% [4] [10]. Additionally Sung et al. demonstrated that recurrence rates in patients who underwent curettage and bone-grafting were much higher than patients treated with a more aggressive and morbid resection and fusion, at $41.2 \%$ and $7.1 \%$ respectively [10]. Recurrence is particularly important and prognostic in certain skeletal areas such as the mobile spine where GCT recurrence may worsen neurologic deficits, increase surgical complexity, or even preclude further surgical treatment [1]. Overall, GCT recurrence in the appendicular or axial skeleton is associated with increased morbidity and poorer outcomes.

The proposed pathophysiological origin of GCT is attributed to partially differentiated osteoblasts that comprise the GCT stromal cells, which over-express RANKL (Ligand for Receptor Activator of NF-Kappa B), cytokines, and chemokines [4] [11] [12]. This over expression of RANKL, a differentiation factor for osteoclasts, drives the formation of multinucleated osteoclast-like giant cells which are responsible for the continued lytic destruction of bone [13] [14]. In recent in vitro studies, bisphosphonates have demonstrated promising results 
and illustrated the clinical potential for these drugs to reduce recurrence rates and control progression of GCT by inducing apoptosis in the proliferating GCT stromal cells [1] [3] [15]. Denosumab, a RANK Ligand inhibitor antibody, is another promising targeted therapy in the systemic treatment of GCT. Denosumab directly affects the proliferation and lytic destruction of the multi-nucleated giant cells by interfering with the RANK-L/RANK pathway but whether it has efficacy against the neoplastic stromal cell component of GCT is still under investigation.

Historically, these systemic anti-osteoclastic agents have been used with good efficacy in the treatment of other osteolytic bone disease such as multiple myeloma and carcinomas that have spread to bone [16] [17]. In recent years, a small number of non-randomized studies have demonstrated that the use of adjuvant anti-osteoclastic agents, in combination with conventional treatment (aggressive curettage, and physical and chemical agents within the bone cavity) may lead to lower recurrence rates while maximally preserving native joint mobility and functionality in patients with GCT (see Figure 1) [2] [18]. Additionally, in cases of unresectable and recurrent GCT of bone, systemic medical treatment may be initiated before or even without accompanying surgical intervention, possibly leading to decreased rates of tumor progression and stabilization of disease [17].

Currently there is no clear consensus regarding the use of systemic bisphosphonates or RANK-L inhibitor treatment in patients with resectable and unresectable cases of GCT. With only a handful of retrospective studies reporting the long-term results of systemic treatment in patients with GCT, it remains challenging to establish an evidence-based systemic treatment protocol for this primary bone tumor. The purpose of this study was to conduct a systematic review of the literature to evaluate the efficacy and safety profiles of systemic treatments by looking at recurrence rates, patient reported outcomes, and complications. Our review examined the existing literature on patients undergoing systemic bisphosphonate or RANK-L inhibitor in cases of both resectable and unresectable GCT to address the following questions:

1) What are the current systemic therapy regimens reported in the literature?

2) Are there differences in recurrence rates or outcomes in patients receiving systemic treatment for GCT with respect to controls?

3) Is there a role for systemic therapies in unresectable cases of GCT?

4) What are the reported side effects and complications of systemic therapy?

5) Does the current literature weakly, moderately, or strongly support a systemic treatment as the standard of care in patients with GCT?

\section{Materials and Methods}

We searched the MEDLINE database using the PUBMED electronic search engine from January 1950 through

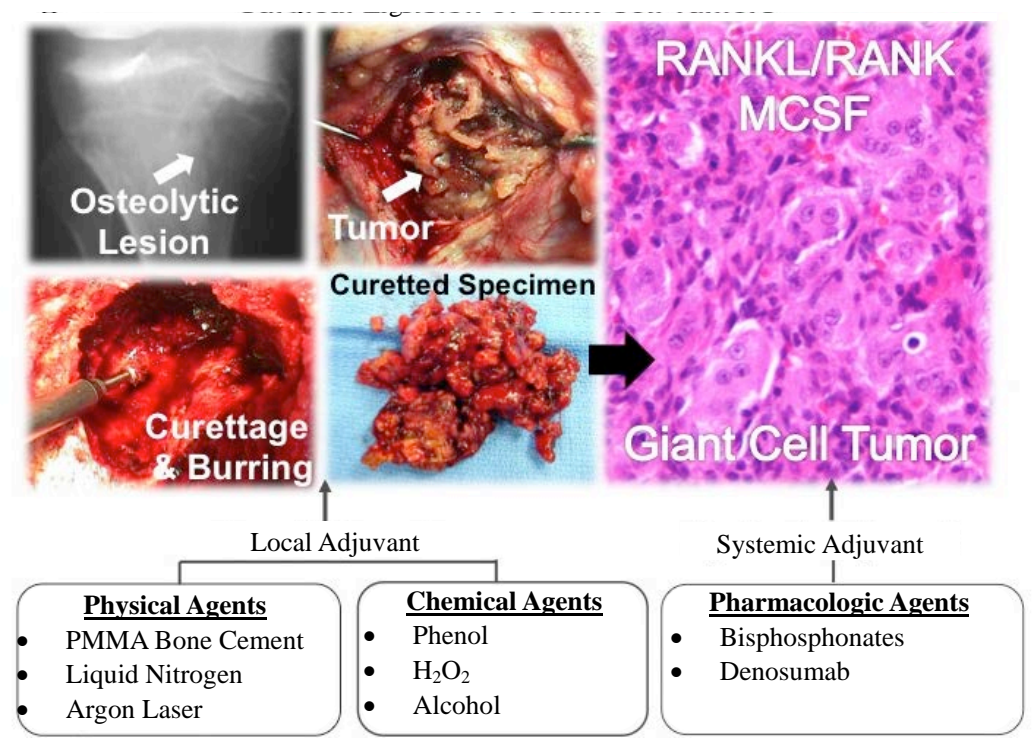

Figure 1. Surgical excision of giant cell tumors. 
January 2014 using the search terms and their respective combinations listed in Table 1.

Only articles that were published in the English language and could be retrieved were included. Studies reporting clinical outcomes in patients with GCT, of which at least one subgroup received systemic bisphophonate or RANK-L inhibitor treatment, were eligible for inclusion in our review. Our inclusion criteria were as follows: 1) studies that reported on a series of patients with resectable or unresectable cases of GCT 2) a subset of patients must have been treated with systemic bisphosphonate or RANK-L inhibitor therapy 3) each series had a minimum of 10 patients with histopathologically confirmed GCT 4) each series stated their follow-up period.

The titles and abstracts of all articles $(\mathrm{n}=998)$ obtained during our MEDLINE database search were reviewed to determine their relevancy to our search inquiry. To minimize reviewer bias, effort was made to conceal all institutional and author information. In total 24 articles published in English were selected for further full text review. Articles that did not report patient specific data or outcomes following systemic treatment for GCT were excluded. In some cases, multiple studies from the same institution reported on the same group of patients undergoing systemic treatment for GCT. In these instances, only the most recent and largest series of patients were included in this review.

Eight studies met our inclusion criteria. Two studies were excluded since they utilized a redundant patient population. This yielded a total of 6 retrospective studies reporting on the outcomes of patients with cases of resectable or unresectable GCT receiving systemic bisphosphonate or RANK-L inhibitor treatment (Figure 2). For analysis, these 6 retrospective studies were subdivided into series where all GCT patients had resectable tumors $(n=4)$ and series where patients had a mix of resectable and unresectable tumors $(n=2)$.

Background information was obtained for each article in our review, which included year of publication, authorship, journal of publication, and level of evidence. Retrieved clinical data from each study included patient demographics, GCT location and grade, whether the GCT was resectable or unresectable, type and regimen of

Table 1. Search Terms entered into MEDLINE database from Time Period January 1950 to January 2014.

\begin{tabular}{cc} 
No. search term & \# Resulted \\
\hline 1. Giant cell tumor AND treatment & 959 \\
2. Giant cell tumor AND bisphosphonate & 12 \\
3. Giant cell tumor AND denosumab & 27 \\
\hline
\end{tabular}

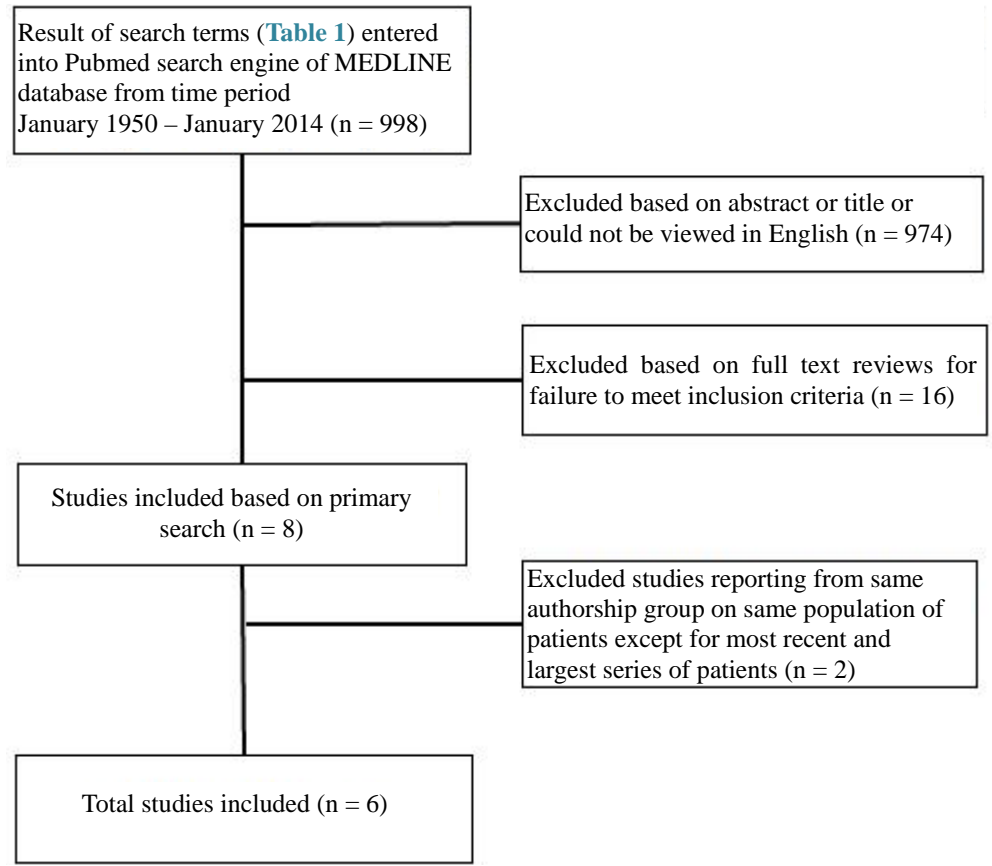

Figure 2. Flow diagram for systematic review literature search. 
systemic treatment, surgical technique in resectable cases, additional treatments, patient clinical outcomes, follow-up radiographic, recurrence rates, and complications related to systemic therapy.

\section{Results}

Overall six papers, reporting on a total of 487 patients, were selected for inclusion in this review. Each study reported clinical outcomes of patients who had histologically confirmed GCT, in which at least one subgroup of patients were treated with systemic bisphosphonate or RANK-L inhibitor therapy. Systemic therapy in resectable cases was pre-operative, post-operative, or a combination of both (peri-operative). Each series explicitly stated their inclusion and exclusion criteria as well their favored regimen of medical therapy. All studies selected were retrospective reviews (level 4) and, when suitable, homogeneous outcomes across studies were aggregated for meta-analysis. For our analysis, studies were subdivided into series where all patients had resectable GCT (n $=4)$ or series where patients had either resectable or unresectable GCT $(n=2)$.

\section{Resectable GCT Studies}

\subsection{Demographics and Adjuvant Systemic Treatment Type}

A total of 4 studies, comprising 180 patients (range: 16 to 102 per study) were included in this portion of the review and systemic treatment in these 4 studies was comprised of varying adjuvant (pre-operative, post-operative, and peri-operative) regimens of bisphophonates [1]-[4]. Two studies [1] [4] $(\mathrm{n}=146)$ used a regimen of preoperative and post-operative bisphosphonates (peri-operative) while the remaining two studies [2] [3] ( $\mathrm{n}=34)$ used a course of pre-operative or post-operative bisphosphonate treatment only. The bisphosphonate route of administration was either oral or parenteral (intravenous). The demographic data presented in Table 2 shows the mean weighted patient age was 34.1 years (range: 11 to 78 years). In 3 of 4 studies [1] [2] [4] ( $=162)$ that reported patient gender, $56.8 \%$ (92 of 162) of patients were female and $43.2 \%$ (70 of 162) were male. In total, 89 (49.4\%) GCT patients were treated with adjuvant systemic bisphosphonate therapy and 91 (50.6\%) GCT patients did not receive any systemic bisphosphonate therapy. Of note, these 4 studies are largely based on patient populations in Asia (China and Hong Kong) which have an inherently higher incidence of GCT, accounting for approximately $20 \%$ of all primary bone tumors [4].

\subsection{Giant Cell Tumor Characteristics}

The heterogeneous characteristics of resectable GCT were reported in 3 of 4 studies $(n=162)$ and are outlined in Table 3. Overall 78.4\% (127 of 162) of patients had primary cases of GCT and 21.6\% (35 of 162) of patients were being treated for a recurrence. GCT most commonly arose near the epiphyses of the distal femur, proximal tibia, or distal radius but a large series of patients $(n=102)$ had confirmed GCT in the mobile spine. Campanacci or Enneking tumor classification was reported in 3 of 4 studies $(n=162)$.

Table 2. Resectable GCT studies—patient demographics and adjuvant systemic treatment type.

\begin{tabular}{|c|c|c|c|c|c|c|c|}
\hline Author & Year & $\begin{array}{l}\text { Level of } \\
\text { evidence }\end{array}$ & $\begin{array}{l}\text { Adjuvant systemic } \\
\text { treatment type }\end{array}$ & $\begin{array}{c}\text { Total number } \\
\text { of patients }\end{array}$ & $\begin{array}{l}\text { Number of patients systemic } \\
\text { treatment/No systemic treatment }\end{array}$ & Male/female & $\begin{array}{l}\text { Average age in } \\
\text { years (range) }\end{array}$ \\
\hline Yu et al. [2] & 2012 & IV & $\begin{array}{l}\text { Post-operative oral } \\
\text { bisphosphonates }\end{array}$ & 16 & $16 / 0$ & $7 / 9$ & $38(27-78)$ \\
\hline $\mathrm{Xu}$ et al. [1] & 2012 & IV & $\begin{array}{l}\text { Peri-operative IV } \\
\text { bisphosphonates }\end{array}$ & 102 & $37 / 65$ & $36 / 66$ & $32.7(11-65)$ \\
\hline Tse et al. [4] & 2008 & IV & $\begin{array}{l}\text { Peri-operative IV and } \\
\text { oral bisphosphonates }\end{array}$ & 44 & $24 / 20$ & $27 / 17$ & $36(19-62)$ \\
\hline Cheng et al. [3] & 2004 & IV & $\begin{array}{l}\text { Preoperative IV } \\
\text { bisphosphonates }\end{array}$ & 18 & $12 / 6$ & NR & NR \\
\hline Totals & - & - & - & 180 & $89 / 91$ & 70/92 & $34.1^{*}(11-78)$ \\
\hline
\end{tabular}

NR = not reported, ${ }^{*}$ Weighted average. 
Table 3. Resectable GCT studies-tumor characteristics.

\begin{tabular}{ccll}
\hline \multicolumn{1}{c}{ Author } & Primary/recurrence & Tumor locations & \multicolumn{1}{c}{ Tumor grade or stage } \\
\hline $\begin{array}{ccl}\text { Yu } \text { et al. }[2] \\
\text { Xu } \text { et al. }[1]\end{array}$ & $12 / 4$ & Distal Femur & $\begin{array}{l}\text { Campanacci: Grade I = 2, Grade II = 11, } \\
\text { Grade III = 3 }\end{array}$ \\
Tse et al. [4] & $71 / 31$ & Mobile Spine & $\begin{array}{l}\text { Enneking: Stage II = 30, Stage III = 72 } \\
\text { Totals }\end{array}$ \\
\hline
\end{tabular}

\subsection{Adjuvant Systemic Regimens, Surgical Technique, and Additional Treatments}

Adjuvant systemic treatment regimens used in each series are reported in Table 4. Two studies [1] [4] $(\mathrm{n}=146)$ used a regimen of pre-operative and post-operative bisphosphonates (peri-operative) while the remaining two studies [2] [3] ( $n=36)$ employed a course of pre-operative or post-operative bisphosphonate treatment only. The bisphosphonate route of administration was either oral or parenteral (intravenous) or combined (oral and intravenous) and duration of systemic treatment varied between 6 weeks and 2 years. Curettage was performed in all cases of resectable appendicular skeletal tumors while spondylectomy or subtotal resection was performed in cases of GCT in the mobile spine. Additional neoadjuvant, adjuvant, and intra-operative treatments included high-speed burr use for aggressive curettage, exothermic bone cement filling of the tumor cavity, selective artery embolization, local treatment with cisplatin or methotrexate, and radiotherapy.

\subsection{Adjuvant Systemic Treatment Follow-Up and Recurrence Rates}

In total, 89 (49.4\%) GCT patients were treated with adjuvant systemic bisphosphonate therapy and 91 (50.6\%) GCT patients did not receive adjuvant systemic bisphosphonate therapy. The duration of follow-up and overall recurrence rates are reported in Table 5. The mean follow-up duration reported for 162 patients was 49.9 months (range 2 - 192 months) and the length of follow-up for the systemic treatment group and no systemic treatment group were similar. Only 4 of 180 patients (2.2\%) were lost to follow-up. The overall recurrence rate of GCT in patients with resectable tumors treated with adjuvant systemic bisphosphonates was $6.7 \%$ (6 of 89 ) compared to $48.4 \%$ (44 of 91) in patients not treated with adjuvant systemic bisphosphonates. The difference in recurrence rate of GCT was statistically significant using Chi-Squared analysis $(p<0.0001)$. Recurrence rates in the adjuvant systemic treatment groups ranged from $0 \%$ to $10.8 \%$, while recurrence rates in groups who did not receive adjuvant systemic treatment ranged from $30 \%$ to $66.7 \%$ during their respective follow-up periods. Independently, three studies with control groups were powered to show a statistically significant benefit in recurrence free survival (RFS) in patients who were treated with bisphosphonates compared to patients who were not treated with bisphosphonate therapy [1] [3] [4]. In cases of GCT recurrence, the time from surgery to recurrence was typically 14 to 21 months.

\subsection{Patient Outcomes and Radiographic Follow-Up}

Additional patient outcomes and follow-up measures along with reported radiographic data is summarized in Table 6. In general, functional outcomes in GCT patients improved following surgery but the reported results were heterogeneous and did not allow for formal meta-analysis.

\subsection{Side Effects of Adjuvant Systemic Treatment and Study Limitations}

The side effects related to adjuvant systemic bisphosphonate treatment were reported in 3 of 4 series [1] [2] [4] $(\mathrm{n}=77$ of 162) and all 4 series $(\mathrm{n}=180)$ reported study limitations, which are outlined in Table 7 . Side effects related to systemic bisphosphonates were unanimously mild and included 2 patients (2.6\%) who reported acid reflux and mild gastrointestinal distress from alendronate treatment. Monitoring of renal function reported by two studies [1] [4] of patients $(n=61)$ receiving bisphosphonates therapy was unremarkable. In general, reported limitations included short follow-up time, retrospective design of the studies, and small sample sizes with possibility of confounding variables. 
Table 4. Resectable GCT studies—adjuvant systemic treatment regimen, surgical technique, and additional treatments.

\begin{tabular}{|c|c|c|c|c|c|c|}
\hline Author & \multicolumn{3}{|c|}{ Adjuvant systemic treatment regimen } & \multicolumn{3}{|c|}{ Surgical technique and additional treatments } \\
\hline Yu et al. [2] & \multicolumn{3}{|c|}{$\begin{array}{l}\text { Post-operative course of oral alendronate } 10 \mathrm{mg} \text { /day } \\
\text { pulsed for two months with } 1 \text {-month intervals and } \\
\text { continued for } 2 \text { years. }\end{array}$} & \multicolumn{3}{|c|}{$\begin{array}{l}\text { High-speed burr for aggressive curettage, exposed cortical } \\
\text { bone was burned with electric knife, cavity filling with } \\
\text { bone cement, and internal fixation. }\end{array}$} \\
\hline Xu et al. [1] & \multicolumn{2}{|c|}{$\begin{array}{l}\text { IV zoledronic acid } 4 \mathrm{mg}(\mathrm{n}=26) \text { or IV incadronate } \\
\text { disodium } 10 \mathrm{mg}(\mathrm{n}=11) \text { dosed once preoperatively } \\
\text { and one dose every month post-operatively for } 2 \text { years. }\end{array}$} & \multicolumn{4}{|c|}{$\begin{array}{l}\text { En bloc total spondylectomy }(n=36) v \text {. subtotal resection } \\
(n=66) \text {. Additionally treatments included preoperative } \\
\text { selective artery embolization }(n=37) \text {, local treatment with } \\
\text { cisplatin }(n=35) \text { or methotrexate }(n=29) \text {, and adjuvant } \\
\text { radiotherapy }(n=66) \text {. }\end{array}$} \\
\hline Tse et al. [4] & $\begin{array}{l}\text { Pre-operatively } 2 \text { doses of I } \\
\text { or IV zolendronic acid } 4 \mathrm{mg} \\
3 \text { - } 4 \text { weeks. Post-operativel } \\
\text { bisphosphonates at } 3 \text { - } 4 \text { we } \\
\text { oral clodronate for } 3 \text { months }\end{array}$ & $\begin{array}{l}\text { palmidronate } 90 \mathrm{mg}(\mathrm{n} \\
\text { IV }(\mathrm{n}=17) \text { at intervals o } \\
3 \text { more doses of IV } \\
\text { x intervals as well as }\end{array}$ & \multicolumn{4}{|c|}{$\begin{array}{l}\text { Lesions underwent wide excision if subchondral bone was } \\
\text { destroyed or intralesional curettage with subsequent } \\
\text { reconstruction or bone cementation. }\end{array}$} \\
\hline Cheng et al. [3] & $\begin{array}{l}\text { Prior to surgery patients con } \\
\text { IV pamidronate } 90 \mathrm{mg} \text { for } 6\end{array}$ & $\begin{array}{l}\text { pleted weekly doses of } \\
\text { veeks. }\end{array}$ & & \multicolumn{3}{|c|}{ Surgical curettage of tumor site was performed in all patients. } \\
\hline Author & $\begin{array}{l}\text { Number of patients } \\
\text { systemic treatment/ } \\
\text { No systemic treatment }\end{array}$ & $\begin{array}{l}\text { Length of } \\
\text { follow } \\
\text { up (range) }\end{array}$ & $\begin{array}{l}\text { No. lost } \\
\text { to follow } \\
\text { up }(\%)\end{array}$ & $\begin{array}{c}\text { Overall } \\
\text { recurrence } \\
\text { in systemic } \\
\text { treatment group }\end{array}$ & $\begin{array}{c}\text { Overall } \\
\text { recurrence in } \\
\text { non systemic } \\
\text { treatment group }\end{array}$ & $\begin{array}{c}\text { Mean time } \\
\text { from surgery } \\
\text { to recurrence } \\
\text { (range) }\end{array}$ \\
\hline Yu et al. [2] & $16 / 0$ & 28 months (23 - 53) & $0(0)$ & $\mathrm{n}=0 \%, 0 \%$ & NA & NA \\
\hline Xu et al. [1] & $37 / 65$ & 39.9 months $(2-153)$ & $4(3.8)$ & $\begin{array}{l}\mathrm{n}=4 \%, 10.8 \% \\
(5.4 \% \text { at } 2 \text { years })\end{array}$ & $\begin{array}{c}\mathrm{n}=34 \%, 52.3 \% \\
(36.9 \% \text { at } 2 \text { years })\end{array}$ & $\begin{array}{l}20.9 \text { months } \\
(2-82)\end{array}$ \\
\hline Tse et al. [4] & $24 / 20$ & $\begin{array}{l}48 \text { months-treatment } \\
\text { group }(24-84) / \\
115.4 \text { months-control } \\
\text { group }(32-192)\end{array}$ & $0(0)$ & $\mathrm{n}=1 \%, 4.2 \%$ & $\mathrm{n}=6 \%, 30 \%$ & $\begin{array}{l}14.4 \text { months } \\
\quad(9-39)\end{array}$ \\
\hline Cheng et al. [3] & $12 / 6$ & $(12-48)$ & $0(0)$ & $\mathrm{n}=1 \%, 8.3 \%$ & $\mathrm{n}=4 \%, 66.7 \%$ & NR \\
\hline Totals & $89 / 91$ & ${ }^{*} 49.9(2-192)$ & $4(2.2 \%)$ & $\mathrm{n}=6 \%, 6.7 \%$ & $\mathrm{n}=\mathbf{4 4} \%, \mathbf{4 8 . 4} \%$ & (2 - 39) \\
\hline
\end{tabular}

$\mathrm{NR}=$ not reported, NA = not applicable, ${ }^{*}$ Weighted average.

Table 6. Resectable GCT studies—patient outcomes and radiographic follow-up.

\begin{tabular}{|c|c|}
\hline Author/treatment type & Follow-up outcomes measures/radiographs \\
\hline Yu et al. [2]/Bisphosphonates & $\begin{array}{l}\text { Mean Enneking limb function score was } 26.7 \text { (Range } 24 \text { - 29). Radiographic: Lucent zones } \\
\text { observed in } 4 \text { patients (at average of } 8 \text { months) adjacent to the bone cement without progression. } \\
\text { All internal fixation was intact without evidence of subchondral bone fracture. }\end{array}$ \\
\hline Xu et al. [1]/Bisphosphonates & $\begin{array}{l}\text { Independent favorable prognostic factors of overall recurrence free survival (RFS) were age } \\
<40(p<0.01) \text {, total spondylectomy over subtotal }(\mathrm{p}=0.04) \text {, and bisphosphonate therapy }(\mathrm{p}=0.02) \\
\text { Radiographic: Not reported }\end{array}$ \\
\hline Tse et al. [4]/Bisphosphonates & $\begin{array}{l}\text { Pain scores improved in all patients with average visual analog pain scores decreasing from } \\
7.7(5-8) \text { preoperatively to } 3.3(1-4) \text { post-operatively. Also } 20 \text { out of } 24 \text { patients experienced } \\
\text { subjective decrease in swelling. Local recurrence was statistically lower in the bisphosphonate } \\
\text { group (p }=0.056) \text {. Radiographic: Pre-operative radiographic evidence of mineralization was noted } \\
\text { in } 14 \text { of } 24 \text { patients in the bisphosphonate group. }\end{array}$ \\
\hline Cheng et al. [3]/Bisphosphonates & Local recurrence rates were lower in patients treated with pamidronate. Radiographic: Not reported \\
\hline
\end{tabular}

\section{Resectable and Unresectable GCT Studies}

\subsection{Demographics and Systemic Treatment Type}

A total of 2 studies, comprising 307 patients (range: 25 to 282 per study) were included in this portion of the review and systemic treatment in these studies was comprised of varying regimens of peri-operative or post-operative bisphosphonates and the RANK-L inhibitor antibody, denosumab [18] [19]. The route of administration for 
bisphosphonates was either oral or parenteral (intravenous) while denosumab was administered subcutaneously. The demographic data presented in Table 8 show the mean weighted patient age was 33.7 years (range: 15 to 75 years) with a female predominance of $58.6 \%$ (180 of 307) compared to males who comprised $41.4 \%$ (127 of 307) of GCT patients. In these series, 100\% (307 of 307) of GCT patients were assigned to systemic bisphosphonate or denosumab therapy and therefore comparison against a control group was not possible. In the trial by Chawla et al., patients were stratified into 3 cohorts: 1) patients with unresectable GCT, 2) patients with resectable GCT and planned surgery associated with severe morbidity, and 3) a small cohort of patients remaining from a previous denosumab study still with GCT burden [18].

\subsection{Giant Cell Tumor Characteristics}

The heterogeneous characteristics of resectable and unresectable GCT were reported in both studies $(n=307)$ and are outlined in Table 9. Inherently, by study design, this group of patients had a greater propensity for recurrent and primary aggressive cases of GCT. Overall 38.4\% (118 of 307) of patients had primary cases of GCT and 61.6\% (189 of 307) of patients were being treated for a recurrence. In the study by Chawla et al., 68.8\% (194 of 282) of patients were originally identified as having unresectable cases of GCT [18]. The location of GCT in these two series was heterogeneous, reported throughout the appendicular and axial skeleton along with cases that were multi-focal or metastatic often involving the lung. Enneking tumor staging was only reported by Balke et al. [19].

\subsection{Systemic Treatment Regimen, Surgical Technique, and Additional Treatments}

Systemic regimens used in the two series are reported in Table 10. In the study by Balke et al. the bisphosphonate regimen varied considerably [19]. The route of administration was either oral or parenteral (intravenous) or combined (oral and intravenous) and duration of bisphosphonate treatment varied between 6 weeks and 5 years.

Table 7. Resectable GCT studies—side effects of adjuvant systemic treatment and study limitations.

\begin{tabular}{|c|c|c|c|}
\hline Author & Systemic treatment type & Side effects of systemic treatment & Study limitations \\
\hline Yu et al.[2] & $\begin{array}{l}\text { Post-Operative Oral } \\
\text { Bisphosphonates }\end{array}$ & $\begin{array}{l}\text { Two patients reported acid reflux and mild } \\
\text { GI distress from the alendronate treatment }\end{array}$ & Small number of cases and short follow-up time. \\
\hline $\mathrm{Xu}$ et al. $[1]$ & $\begin{array}{l}\text { Peri-Operative IV } \\
\text { Bisphosphonates }\end{array}$ & $\begin{array}{l}\text { None-Renal function was monitored in } \\
\text { each patient before each infusion. }\end{array}$ & Retrospective and short follow-up time \\
\hline Tse et al. [4] & $\begin{array}{l}\text { Peri-Operative IV and } \\
\text { Oral Bisphosphonates }\end{array}$ & $\begin{array}{l}\text { None-Renal function was monitored } \\
\text { in each patient before each infusion. }\end{array}$ & $\begin{array}{l}\text { Retrospective, short follow-up time in } \\
\text { bisphosphonate group, and small sample size. }\end{array}$ \\
\hline Cheng et al. [3] & $\begin{array}{l}\text { Preoperative IV } \\
\text { Bisphosphonates }\end{array}$ & Not reported & $\begin{array}{l}\text { Short follow-up time, small sample size, } \\
\text { and possible confounders. }\end{array}$ \\
\hline
\end{tabular}

Table 8. Resectable and unresectable GCT studies-patient demographics and systemic treatment type.

\begin{tabular}{|c|c|c|c|c|c|c|c|}
\hline Author & Year & $\begin{array}{c}\text { Level } \\
\text { of } \\
\text { evidence }\end{array}$ & $\begin{array}{l}\text { Systemic } \\
\text { treatment } \\
\text { type }\end{array}$ & $\begin{array}{c}\text { Total } \\
\text { number } \\
\text { of patients }\end{array}$ & $\begin{array}{c}\text { Number of patients systemic } \\
\text { treatment/No systemic } \\
\text { treatment }\end{array}$ & Male/female & $\begin{array}{l}\text { Average age } \\
\text { in years } \\
\text { (range) }\end{array}$ \\
\hline Balke et al. [19] & 2010 & IV & $\begin{array}{l}\text { Perioperative or } \\
\text { postoperative or } \\
\text { non-operative IV or } \\
\text { oral bisphosphonates }\end{array}$ & 25 & $25 / 0$ & $9 / 16$ & $38.8(15-75)$ \\
\hline Chawla et al. [18] & 2013 & IV & $\begin{array}{l}\text { Post-operative or } \\
\text { non-operative RANK } \\
\text { ligand antibody }\end{array}$ & 282 & $\begin{array}{l}282 / 0 \\
\text { Cohort I-Surgically unsalvageable } \\
\text { disease }(\mathrm{n}=169) \text { cohort II-Patients } \\
\text { with planned surgery associated with } \\
\text { severe morbidity }(\mathrm{n}=101) \text { cohort } \\
\text { III-Patients in previous study of } \\
\text { denosumab }(\mathrm{n}=11)\end{array}$ & $118 / 164$ & $33.2(24-45)$ \\
\hline Totals & - & - & - & 307 & $307 / 0$ & $127 / 180$ & $33.7^{*}(15-75)$ \\
\hline
\end{tabular}

*Weighted average. One patient from the Cohort I in the denosumab group did not receive systemic treatment and was therefore excluded from subsequent analysis. 
Table 9. Resectable and unresectable GCT studies—-tumor characteristics.

\begin{tabular}{|c|c|c|c|}
\hline Author & Primary/recurrence & Tumor locations & Tumor grade or stage \\
\hline Balke et al. [19] & $5 / 20^{*}$ & $\begin{array}{l}\text { Femur }(n=4) \text { Radius }(n=1) \text {, Sacrum }(n=9) \text {, } \\
\text { Pelvis }(n=3) \text {, Vertebrae }(n=1) \text {, Fibula }(n=2) \text {, } \\
\text { Tibia }(n=2) \text {, Humerus }(n=1) \text {, Multifocal }(n=2)\end{array}$ & $\begin{array}{l}\text { Enneking: all stage } \\
\text { IB or IIIB }\end{array}$ \\
\hline Chawla et al. [18] & $\begin{array}{l}113 / 169 \\
\text { Primary unresectable }=63 \text { of } 113 \\
\text { Recurrent unresectable }=131 \text { of } 169\end{array}$ & $\begin{array}{l}\text { Leg }(n=75) \text {, Lung }(n=49) \text {, Sacrum }(n=48) \text {, } \\
\text { Pelvic bone }(n=46) \text {, Arm }(n=33) \text {, Vertebrae }(n=27) \text {, } \\
\text { Skull }(n=8) \text {, Pelvic soft tissue only }(n=2) \text {, Other }(n=4)\end{array}$ & Not reported \\
\hline Totals & 118/189 & - & - \\
\hline
\end{tabular}

* Primary tumors in this patient population were aggressive or metastatic, 3 of which were unresectable.

Table 10. Resectable and unresectable GCT studies-systemic treatment regimen, surgical technique, and additional treatments.

\begin{tabular}{|c|c|c|c|}
\hline Author & Systemic treatment & Systemic treatment regimen & $\begin{array}{l}\text { Surgical technique and } \\
\text { additional treatments }\end{array}$ \\
\hline $\begin{array}{l}\text { Balke et al. } \\
\text { [19] }\end{array}$ & $\begin{array}{l}\text { Perioperative or } \\
\text { Postoperative } \\
\text { or Non-operative IV } \\
\text { or PO Bisphosphonates }\end{array}$ & $\begin{array}{l}\text { Either perioperative or postoperative or non-operative } \\
\text { IV zoledronic acid } 4 \text { mg for } 1 \text { - } 6 \text { doses over variable } \\
\text { time course }(n=18) \text { or postoperative IV alendronate } \\
70 \text { mg weekly for } 24 \text { - } 32 \text { months }(n=2) \text { or postoperative } \\
\text { or non-operative PO clodronate } 2 \times 800 \text { mg daily for } 12 \\
\text { - } 60 \text { months }(n=4) \text { or postoperative IV pamidronate } \\
90 \text { mg monthly for unknown course }(n=1)\end{array}$ & $\begin{array}{l}\text { Non surgical cases }=3 \text { of } 25(12 \%) \\
\text { In some cases of progressive disease } \\
\text { were treated with preoperative } \\
\text { selective artery embolization, adjuvant } \\
\text { radiotherapy, or other systemic } \\
\text { chemotherapy. }\end{array}$ \\
\hline $\begin{array}{c}\text { Chawla et al. } \\
\text { [18] }\end{array}$ & $\begin{array}{l}\text { Post-operative or } \\
\text { Non-operative RANK } \\
\text { Ligand Antibody }\end{array}$ & $\begin{array}{l}\text { Cohorts } 1 \text { and } 2^{*} \text {-Subcutaneous denosumab } 120 \mathrm{mg} \\
\text { every } 4 \text { weeks (plus additional doses on day } 8 \text { and } 15 \\
\text { in first cycle only). Eventual surgical patients in cohort } \\
2 \text { received } 6 \text { doses of denosumab postoperatively ( } \mathrm{n}=26 \text { ). } \\
\text { The median number of doses across all cohorts was } 13.0 \\
\left(7.0 \text { - 20.0). Cohort } 3^{*} \text {-Continued previous regimen }\right. \\
\text { (denosumab } 120 \mathrm{mg} \text { every } 4 \text { weeks). }\end{array}$ & $\begin{array}{l}\text { Past treatments included surgery, } \\
\text { radiation, chemotherapy or } \\
\text { immunotherapy, IV or oral } \\
\text { bisphosphonates. }\end{array}$ \\
\hline
\end{tabular}

*All patients were advised to take $500 \mathrm{mg}$ of calcium and 400IU of Vitamin D daily.

In the trial reported by Chawla et al., denosumab was delivered subcutaneously and the duration of treatment was undefined [18]. Systemic treatment with denosumab continued until one of the following: 1) disease progression 2) recommendation of discontinuation by investigator or sponsor 3) absence of benefit in provider's opinion, 4) patient's decision to discontinue 5) pregnancy or 6) administration of any proscribed treatments [18]. Additionally, patients in the denosumab trial were encouraged to take $500 \mathrm{mg}$ of calcium and 400IU of Vitamin D daily. Previous adjuvant and neoadjuvant therapies for patients with GCT reported in these two studies included preoperative selective artery embolization, radiotherapy, chemotherapy (interferon alpha, ifosamide, cyclophosphamide, cisplatin, adriamycin), bisphosphonates, and prior surgery. Patients who received denosumab and bisphosphonates concurrently in the trial reported by Chawla et al. were excluded from evaluation [18].

\subsection{Systemic Treatment Follow-Up and Recurrence Rates}

In total, 306 (100.0\%) GCT patients were treated with systemic bisphosphonate or denosumab therapy. The duration of follow-up and cases of recurrence or disease progression, diagnosed by an increase in tumor activity or burden radiographically, are reported in Table 11. The mean follow-up duration reported for 306 patients was 11.8 months (range 3 - 60 months) and only 3 patients (1.0\%) were lost to follow-up. In the study by Balke et al, the overall rate of recurrence (resectable) or disease progression (unresectable) in patients with recurrent or aggressive primary GCT was $16 \%(n=4)$ [19]. In the trial of denosumab therapy, Chawla et al. stratified results by patients with unresectable GCT (cohort I) and patients with resectable GCT and planned surgery associated with severe morbidity (cohort II) [18]. In cohort I, 3.5\% $(n=6)$ of patients had disease progression at range of 85 - 498 days after first denosumab dose. At a minimum of one time point, 99\% (158 of 159) of analyzed patients were determined to have a best response of stable disease or better: Eight patients (5\%) had a complete response and 57 (36\%) had a partial response, ninety-three patients (58\%) had stable disease and 1 patient (1\%) had disease progression. In cohort II, 74\% (74 of 100) of patients identified as having resectable disease were 
able to avoid surgery due to treatment response at the time of analysis (average 9.2 months). Of the remaining 26 patients who underwent surgery, 16 (61.5\%) had a less morbid surgical procedure, 9 (34.6\%) underwent the anticipated procedure, and 1 (3.8\%) patient underwent a surgery of increased morbidity (en-bloc resection versus curettage). While neither study in this portion of the review contained a control group, the overall percentages of GCT recurrence and disease progression are below the historic norms reported in the literature in cases of primary aggressive, metastatic, and recurrent cases of GCT [1] [2] [7].

\subsection{Patient Outcomes and Radiographic Follow-Up}

Additional patient outcomes and follow-up measures along with reported radiographic data are summarized in Table 12. In general, functional outcomes in GCT patients improved following surgery but the reported results were heterogeneous and did not allow for formal meta-analysis.

\section{Side Effects of Systemic Treatment and Study Limitations}

The side effects related to systemic bisphosphonate and denosumab are outlined in Table 13. Similar to the cohort of studies $(n=4)$ in which all patients had resectable GCT, bisphosphonate use was generally safe and no adverse events were reported by Balke et al. [19]. In contrast, the ongoing trial of denosumab therapy in GCT patients has reported higher rates of side effects and adverse events [18]. In total 84\% (236 of 281) of patients receiving denosumab suffered at least one side effect including: arthralgia (20\%), headache (18\%), nausea (17\%), fatigue (16\%), back pain (15\%), and extremity pain (15\%). Grade 3, 4, or 5 adverse events occur in $18 \%$ $(\mathrm{n}=50)$ of patients overall and included: hypophosphatemia (3\%), hypocalcemia (5\%), anemia (1\%), back pain (1\%), pain in extremity (1\%), arthralgia (1\%), depression (1\%), headache (1\%), musculoskeletal pain (1\%), osteomyelitis (1\%), osteonecrosis of the jaw (1\%), and weight gain (1\%). Osteonecrosis of the jaw occurred 13 to 20 months after initiation of denosumab treatment and resolved in 2 of 3 patients. Serious adverse events, both related and unrelated to denosumab, occurred in $9 \%(\mathrm{n}=25)$ of patients, which led to treatment and study

Table 11. Resectable and unresectable GCT studies—systemic treatment follow-up and recurrence rates.

\begin{tabular}{|c|c|c|c|c|c|}
\hline $\begin{array}{l}\text { Author/systemic } \\
\text { treatment type }\end{array}$ & $\begin{array}{l}\text { Number of } \\
\text { patients systemic } \\
\text { treatment/No } \\
\text { systemic treatment }\end{array}$ & $\begin{array}{l}\text { Length of follow } \\
\text { up (range) }\end{array}$ & $\begin{array}{c}\text { No. lost to } \\
\text { follow up (\%) }\end{array}$ & $\begin{array}{c}\text { Overall } \\
\text { recurrence/progression } \\
\text { in systemic } \\
\text { treatment group }\end{array}$ & $\begin{array}{l}\text { Mean time from } \\
\text { surgery to } \\
\text { recurrence (range) }\end{array}$ \\
\hline $\begin{array}{l}\text { Balke et al. [19]/ } \\
\text { Bisphosphonates }\end{array}$ & $25 / 0$ & 27.0 Months (3 - 60) & $0(0 \%)$ & $\mathrm{n}=4 \%, 16.0 \%$ & NR \\
\hline $\begin{array}{l}\text { Chawla et al. [18]/ } \\
\text { RANK Ligand } \\
\text { Antibody }\end{array}$ & $281 / 0$ & $\begin{array}{l}\text { Overall } 10.4 \text { Months }(5.3-16.7) \text {. } \\
\text { Cohort } 1(n=169)-13.0 \text { months, } \\
\text { Cohort } 2(n=100)-9.2 \text { months } \\
(4.2-12.9)\end{array}$ & $3(1.1 \%)$ & Cohort $1 \mathrm{n}=6 \%, 3.5 \%$ & Cohort 2 - 723 days \\
\hline Totals & $306 / 0$ & 11.8 months & $1.0 \%$ & - & - \\
\hline
\end{tabular}

NR = not reported. Weighted average reported for length of follow-up. In the Chawla et al. [18] study, one patient never received any systemic treatment decreasing their total number of studied patients from 282 to 281.

Table 12. Resectable and unresectable GCT studies—systemic treatment outcomes and radiographs.

Author/treatment type

Balke et al. [19]/ Bisphosphonates

Chawla et al. [18]/ RANK Ligand Antibody

\section{Follow up outcomes measures/radiographs}

Post treatment clinical outcomes were heterogeneous but included: stable tumor size $(n=11)$, decrease in tumor size $(n=1)$, decrease in pain $(n=8)$, no further recurrence $(n=12)$, stable lung metastases $(n=9)$, disease progression $(n=3)$, recurrence $(n=1)$ Radiographic: Metastases did not increase in size or number when assessed by lung CT or X-ray in patients during the follow-up period.

Cohort 1-Clinical benefit was seen in 67 of 169 (41\%) patients and included pain reduction in 28\%, improved mobility in 22\%, and improved function in 19\%. Cohort 2-Clinical benefit was seen in 61 of 100 (61\%) patients and included pain reduction in 50\%, improved mobility in 33\%, and improved function in 23\%. Radiographic:

An objective radiographic complete or partial response was noted in 136 of 187 (72\%) analyzed patients. By modified RECIST criteria, 47 of 187 (25\%) had responses. The median time to radiographic response was 3.1 months and this response was maintained for at least 24 weeks in 76 of 111 (67\%) patients analyzed with at additional time points. 
Table 13. Resectable and unresectable GCT studies—side effects of systemic treatment and study limitations.

\begin{tabular}{|c|c|c|c|}
\hline $\begin{array}{l}\text { Author/systemic } \\
\text { treatment type }\end{array}$ & Side effects of medical treatment & Other adverse events/discontinuation & Study limitations \\
\hline $\begin{array}{l}\text { Balke et al. [19]/ } \\
\text { Bisphosphonates }\end{array}$ & None & $\begin{array}{l}\text { One patient with extensive pelvic } \\
\text { disease died intraoperatively }\end{array}$ & Different treatment protocols \\
\hline $\begin{array}{l}\text { Chawla et al. } \\
\text { [18]/RANK Ligand } \\
\text { Antibody }\end{array}$ & $\begin{array}{l}84 \%(n=236) \text { of patient suffered at least } \\
\text { one side effect. Grade } 3,4 \text {, or } 5 \text { adverse } \\
\text { events occur in } 18 \%(n=50) \text { of patients. } \\
\text { Serious adverse (both related and unrelated } \\
\text { to denosumab) events were noted in } 9 \% \\
(n=25) \text { of patients. Adverse events leading } \\
\text { to treatment and study discontinuation } \\
\text { occurred } 5 \%(n=14) \text { and } 5 \%(n=13) \\
\text { of patients respectively. }\end{array}$ & $\begin{array}{l}\text { One patient died from respiratory failure } \\
\text { during the study unrelated to denosumab } \\
\text { therapy. } 21 \text { patients discontinued the study } \\
\text { in Cohort } 1 \text { and } 20 \text { patients discontinued } \\
\text { the study in Cohort } 2 \text { : Other adverse } \\
\text { events: serious infections }(2 \%, n=5) \text {, } \\
\text { and new primary malignancy }(1 \%, n=3) \text {. }\end{array}$ & $\begin{array}{l}\text { Short follow-up time, no } \\
\text { placebo group, and } \\
\text { non-uniform follow-up } \\
\text { amongst treating physicians }\end{array}$ \\
\hline
\end{tabular}

discontinuation in 5\% $(n=14)$ and $5 \%(n=13)$ patients, respectively. In general, reported limitations of these studies included short follow-up time and the variability of multiple prior treatments given the heterogeneous course of patients with primary aggressive, recurrent, and metastatic GCT.

\section{Discussion}

Several systemic therapies have been reported in the literature with regard to the treatment of GCT in addition to local adjuvant therapies (Figure 1). Current management of GCT remains largely predicated on non-randomized studies and single-institution retrospective data [20]. In cases of wide-spread or aggressive GCT, the goal of treatment is stabilization of the disease while in less aggressive and resectable cases the goal of treatment is surgical removal and cure [19]. Historically, non-targeted systemic treatments such as cytotoxic chemotherapy were used to treat patients with GCT [21]-[24]. For instance, interferon-alpha (INF- $\alpha$ ) had been used in GCT patients to target the hypoxia-angiogenesis axis, by inhibiting beta-FGF and IL-8, two angiogenic factors [25] [26]. However past non-targeted chemotherapeutic treatments for GCT patients, including INF- $\alpha$, were accompanied by significant side effects and their reported efficacy in the literature was variable [27] [28]. Newer therapies such as bisphosphonates and denosumab target the RANKL/RANK pathway. Bisphosphonates cause osteoclast apoptosis, resulting in an overall decrease in bone absorption. Denosumab interrupts RANKL signaling, which reduces the number of RANK-positive giant cells and also has been hypothesized to inhibit pathways in the neoplastic stromal cell component of GCT but further study is necessary [17]. While both bisphosphonates and denosumab potentially inhibit multiple cell types, it has been speculated that denosumab may be more effective than bisphosphonates in specifically targeting the osteolytic and neoplastic components of GCT [29].

The benefit of systemic treatment with bisphosphonates or denosumab in both resectable and unresectable cases of GCT is encouraging. Our meta-analysis showed the overall recurrence rates of GCT in patients with resectable disease treated with adjuvant systemic bisphosphonates was $6.7 \%$ compared to $48.4 \%$ in patients not treated with adjuvant systemic bisphosphonates. The difference in recurrence rate of GCT was statistically significant using Chi-Squared analysis $(\mathrm{p}<0.0001)$ and independently, all three studies with a control group were powered sufficiently to show a statistically significant benefit in recurrence free survival (RFS) in patients who were treated with adjuvant systemic bisphosphonates [1] [3] [4]. In patients with both resectable and unresectable primary aggressive, recurrent, or metastatic GCT disease, Balke et al, demonstrated an overall rate of recurrence (resectable) or disease progression (unresectable) of 16\% in patients undergoing systemic bisphosphonate treatment [19]. Additionally, the on-going trial of denosumab therapy reported by Chawla et al. [18], demonstrated that only 3.5\% of patients with unresectable disease had disease progression within the follow-up period and $74 \%$ of patients identified as having resectable disease were able to avoid surgery due to treatment response at the time of analysis (average 9.2 months). Of the remaining patients who underwent surgery, 96.2\% had a less morbid or equally morbid surgical procedure. While neither study reported by Balke et al. [19] or Chawla et al. [18] in this portion of the review contained a control group, the overall percentages of GCT recurrence and disease progression are below the historic norms reported in the literature in cases of primary aggressive, metastatic, and recurrent cases of GCT [1] [2] [7]. While the open-label phase 2 study of denosumab in GCT patients showed a positive tumor response, Balke et al. [30] noted the follow up period in this study is still short of the 12 to 24 month range necessary to detect true recurrence. 
In cases of resectable GCT, local recurrences typically occur at the surgical margin within three years in $80 \%$ - 90\% of cases [31] [32]. Radiographic features of GCT recurrence include: 1) progressive lysis of the incorporated bone graft 2) failure to develop a radiolucent zone around the thin $(2 \mathrm{~mm})$ sclerotic rim between the bone cement and cancellous bone; an osteolytic zone caused by thermal injury [31] [33]-[35]. Recurrence of GCT in the soft-tissues can arise when tumor debris is implanted at the time of surgery [31]. In cases of soft tissue recurrence it was originally thought a peripheral rim of ossification was the pathognomonic sign of soft-tissue recurrence [31] [36] [37]. However, soft-tissue recurrence of GCT can occur without characteristic ossification and in these instances, diagnosis depends on physical examination and subsequent magnetic resonance imaging (MRI) scan demonstrating a heterogeneous signal pattern within a soft-tissue lesion [36]. MRI remains the best modality for detecting recurrent or residual disease. Local recurrence is associated with an area of high MRI signal and eccentric growth within the original surgical cavity that typically occurs within 18 months of surgery [31] [38]. Giant cell granulomas within the tumor bed can mimic recurrence, however these tend to develop more slowly over the course of several years [31]. Newer techniques in the detection of malignant and benign primary bone tumors include the use of fluorodeoxyglucose (FDG) detectable by PET, indicating a role for FDG-PET as a biomarker for monitoring disease progression, recurrence, and response to treatment. Interestingly, while most benign primary bone tumors demonstrate a low uptake of the FDG biomarker, GCT actually demonstrates a high up-take. In general, establishing a sensitive, specific, and cost-effective technique for the detection of GCT in the bone and soft tissues is an important aspect of timely and effective treatment in cases of primary and recurrent GCT [36].

Complications and side effects directly related to long-term inhibition of the RANK/RANKL signal transduction pathway have been studied closely in the context of osteoporosis management. With long-term treatment at higher cumulative doses, bisphosphonates can exhibit renal toxicity (acute tubular necrosis), flu-like symptoms (with intravenous aminobisphosphonates only), and gastrointestinal toxicity in the form of ulcers, flatulence, and diarrhea (oral administration only) [39]-[45]. More rarely, patients taking bisphosphonates experiences hypocalcemia, ocular complications, asthma, erythema, phlebitis, altered taste, and central nervous system problems [46]. In the past decade, over 1000 cases in the US of osteonecrosis of the jaw have been reported in association with long-term aminobisphosphonate use [47] [48]. However, in our review, reported side effects for 102 patients related to systemic bisphosphonate included only 2 patients (2.0\%) with acid reflux and mild gastrointestinal distress from alendronate treatment and there were no changes in the renal function of patients who were monitored. We believe a 6-week peri-operative bisphosphonate treatment demonstrates a relatively safe side effect profile, however the patient should be aware of the complications reported in the literature related to long-term bisphosphonate treatment with higher cumulative doses. The phase 2 study evaluating the safety and efficacy of denosumab for skeletally mature patients with GCT found adverse events related to long-term treatment with denosumab consistent with the known safety profile [18]. In total, $84 \%$ of patients suffered at least one side effect. Patients most commonly experienced hypophosphatemia, anemia, back pain, and extremity pain. Grade 3, 4, or 5 adverse events occurred in 18\% of patients overall and included: hypophosphatemia, hypocalcemia, anemia, osteomyelitis, and osteonecrosis of the jaw. Osteonecrosis of the jaw occurred in 3 patients (1\%) at 13 to 20 months after initiation of denosumab treatment. Long-term treatment with denosumab in osteoporotic patients in the FREEDOM trial revealed an association with dermatologic complications (eczema and cellulitis), and the DEFEND trial showed an increase in the rate of community-acquired infections in hospitalized subjects [49] [50]. However, the overall incidence of infections as reported by the DECID and STAND trials showed no significant difference between placebo and treatment groups [51] [52]. The proven efficacy of denosumab, especially against more aggressive, recurrent, and metastatic forms of GCT must be balanced against the reported 20\% likelihood of a patient experiencing a serious adverse event during their treatment. Despite the side effects, we believe denosumab is an exciting new targeted therapy that will play an important and considerable role in the peri-operative (resectable) and non-operative (unresectable) management of patients with GCT. As of June 2013, denosumab was approved in the United States for treatment in patients with unresectable GCT or where surgical removal is likely to result in severe morbidity [53].

\section{Summary}

In summary, the benefit of systemic treatment with bisphosphonates or denosumab in both resectable and unresectable cases of GCT is promising, but the paucity of high-level evidence with sufficient follow-up supporting 
their use remains. At this time we believe there is moderate support to recommend a short course of adjuvant peri-operative systemic bisphosphonate treatment for patients with resectable primary GCT and moderate support to recommend adjuvant peri-operative (resectable) and non-operative (unresectable) use of denosumab in cases of primary aggressive, recurrent, or metastatic GCT. With either systemic treatment, patients should be well counseled on all potential side effects in addition to alternative treatment, which includes the option of no systemic treatment. Limitations to this review are inherent to the comprising studies and include short follow-up time, retrospective design of the studies, small sample sizes, generalizability as studies were largely based on Asian populations which have higher incidences of GCT, and the variability of prior treatments in GCT patients. Additionally, the inclusion criteria and/or randomization of patients who received adjuvant systemic therapy were unclear in most studies. Randomized clinical trials on this subject in the future will better control for baseline patient and GCT characteristics. Finally, this review of targeted systemic therapies in the treatment of GCT patients brings orthopaedists and oncologists closer to adopting a new standard of care however further study with prospective data and longer follow-up is necessary.

\section{References}

[1] Xu, W., et al. (2012) Factors Affecting Prognosis of Patients with Giant Cell Tumors of the Mobile Spine: Retrospective Analysis of 102 Patients in a Single Center. Annals of Surgical Oncology, 20, 804-810. http://dx.doi.org/10.1245/s10434-012-2707-6

[2] Yu, X. (2012) Clinical Outcomes of Giant Cell Tumor of Bone Treated with Bone Cement Filling and Internal Fixation, and Oral Bisphosphonates. Oncology Letters, 5, 447-451.

[3] Cheng, Y.Y., et al. (2004) Bisphosphonates Induce Apoptosis of Stromal Tumor Cells in Giant Cell Tumor of Bone. Calcified Tissue International, 75, 1-7. http://dx.doi.org/10.1007/s00223-004-0120-2

[4] Tse, L.F., et al. (2008) Bisphosphonates Reduce Local Recurrence in Extremity Giant Cell Tumor of Bone: A CaseControl Study. Bone, 42, 68-73. http://dx.doi.org/10.1016/j.bone.2007.08.038

[5] Kim, Y., Nizami, S., Goto, H. and Lee, F.Y. (2012) Modern Interpretation of Giant Cell Tumor of Bone: Predominantly Osteoclastogenic Stromal Tumor. Clinics in Orthopedic Surgery, 4, 107-116. http://dx.doi.org/10.4055/cios.2012.4.2.107

[6] Liao, T.S., et al. (2005) Recruitment of Osteoclast Precursors by Stromal Cell Derived Factor-1 (SDF-1) in Giant Cell Tumor of Bone. Journal of Orthopaedic Research, 23, 203-209. http://dx.doi.org/10.1016/j.orthres.2004.06.018

[7] Klenke, F.M., Wenger, D.E., Inwards, C.Y., Rose, P.S. and Sim, F.H. (2010) Recurrent Giant Cell Tumor of Long Bones: Analysis of Surgical Management. Clinical Orthopaedics and Related Research, 469, 1181-1187. http://dx.doi.org/10.1007/s11999-010-1560-9

[8] Algawahmed, H., Turcotte, R., Farrokhyar, F. and Ghert, M. (2010) High-Speed Burring with and without the Use of Surgical Adjuvants in the Intralesional Management of Giant Cell Tumor of Bone: A Systematic Review and MetaAnalysis. Sarcoma, 2010, 1-5. http://dx.doi.org/10.1155/2010/586090

[9] Kafchitsas, K., Habermann, B., Proschek, D., Kurth, A. and Eberhardt, C. (2010) Functional Results after Giant Cell Tumor Operation near Knee Joint and the Cement Radiolucent Zone as Indicator of Recurrence. Anticancer Research, 30, 3795-3799.

[10] Sung, H.W., et al. (1982) Giant-Cell Tumor of Bone: Analysis of Two Hundred and Eight Cases in Chinese Patients. Journal of Bone and Joint Surgery, 64, 755-761.

[11] Wülling, M., et al. (2001) The Nature of Giant Cell Tumor of Bone. Journal of Cancer Research and Clinical Oncology, 127, 467-474. http://dx.doi.org/10.1007/s004320100234

[12] Huang, L., Teng, X.Y., Cheng, Y.Y., Lee, K.M. and Kumta, S.M. (2004) Expression of Preosteoblast Markers and Cbfa-1 and Osterix Gene Transcripts in Stromal Tumour Cells of Giant Cell Tumour of Bone. Bone, 34, 393-401. http://dx.doi.org/10.1016/j.bone.2003.10.013

[13] Huang, L., Xu, J., Wood, D.J. and Zheng, M.H. (2000) Gene Expression of Osteoprotegerin Ligand, Osteoprotegerin, and Receptor Activator of NF-KappaB in Giant Cell Tumor of Bone: Possible Involvement in Tumor Cell-Induced Osteoclast-Like Cell Formation. American Journal of Pathology, 156, 761-767. http://dx.doi.org/10.1016/S0002-9440(10)64942-5

[14] Zheng, M.H., et al. (2001) The Histogenesis of Giant Cell Tumour of Bone: A Model of Interaction between Neoplastic Cells and Osteoclasts. Histology and Histopathology, 16, 297-307.

[15] Chang, S.S., et al. (2004) Bisphosphonates May Reduce Recurrence in Giant Cell Tumor by Inducing Apoptosis. Clinical Orthopaedics and Related Research, 426, 103-109. http://dx.doi.org/10.1097/01.blo.0000141372.54456.80 
[16] Lipton, A., et al. (2000) Pamidronate Prevents Skeletal Complications and Is Effective Palliative Treatment in Women with Breast Carcinoma and Osteolytic Bone Metastases: Long Term Follow-Up of Two Randomized, Placebo-Controlled Trials. Cancer, 88, 1082-1090. http://dx.doi.org/10.1002/(SICI)1097-0142(20000301)88:5<1082::AID-CNCR20>3.0.CO;2-Z

[17] Branstetter, D.G., et al. (2012) Denosumab Induces Tumor Reduction and Bone Formation in Patients with Giant-Cell Tumor of Bone. Clinical Cancer Research, 18, 4415-4424. http://dx.doi.org/10.1158/1078-0432.CCR-12-0578

[18] Chawla, S., et al. (2013) Safety and Efficacy of Denosumab for Adults and Skeletally Mature Adolescents with Giant Cell Tumour of Bone: Interim Analysis of an Open-Label, Parallel-Group, Phase 2 Study. Lancet Oncology, 14, 901908. http://dx.doi.org/10.1016/S1470-2045(13)70277-8

[19] Balke, M., et al. (2010) Bisphosphonate Treatment of Aggressive Primary, Recurrent and Metastatic Giant Cell Tumour of Bone. BMC Cancer, 10, 462. http://dx.doi.org/10.1186/1471-2407-10-462

[20] Thomas, D. M. \& Skubitz, K. M. (2009) Giant cell tumour of bone. Current Opinion in Oncology, 21, 338-344. http://dx.doi.org/10.1097/CCO.0b013e32832c951d

[21] Anract, P., De Pinieux, G., Cottias, P., Pouillart, P., Forest, M. and Tomeno, B. (1998) Malignant Giant-Cell Tumours of Bone. Clinico-Pathological Types and Prognosis: A Review of 29 Cases. International Orthopaedics, 22, 19-26. http://dx.doi.org/10.1007/s002640050201

[22] Osaka, S., Toriyama, M., Taira, K., Sano, S. and Saotome, K. (1997) Analysis of Giant Cell Tumor of Bone with Pulmonary Metastases. Clinical Orthopaedics and Related Research, 335, 253-261.

[23] Dominkus, M., Ruggieri, P., Bertoni, F., Briccoli, A., Picci, P., Rocca, M. and Mercuri, M. (2006) Histologically Verified Lung Metastases in Benign Giant Cell Tumours-14 Cases from a Single Institution. International Orthopaedics, 30, 499-504. http://dx.doi.org/10.1007/s00264-006-0204-x

[24] Bertoni, F., Present, D. and Enneking, W.F. (1985) Giant-Cell Tumor of Bone with Pulmonary Metastases. The Journal of Bone and Joint Surgery (American Volume), 67, 890-900.

[25] Singh, R.K., Gutman, M., Bucana, C.D., Sanchez, R., Llansa, N. and Fidler, I.J. (1995) Interferons Alpha and Beta Down-Regulate the Expression of Basic Fibroblast Growth Factor in Human Carcinomas. Proceedings of the National Academy of Sciences of the United States of America, 92, 4562-4566. http://dx.doi.org/10.1073/pnas.92.10.4562

[26] Taylor, J.L. and Grossberg, S.E. (1998) The Effects of Interferon-Alpha on the Production and Action of Other Cytokines. Seminars in Oncology, 25, 23-29.

[27] Kaiser, U., Neumann, K. and Havemann, K. (1993) Generalised Giant-Cell Tumour of Bone: Successful Treatment of Pulmonary Metastases with Interferon Alpha, a Case Report. Journal of Cancer Research and Clinical Oncology, 119, 301-303. http://dx.doi.org/10.1007/BF01212729

[28] Kaban, L.B., Troulis, M.J., Wilkinson, M.S., Ebb, D. and Dodson, T.B. (2007) Adjuvant Antiangiogenic Therapy for Giant Cell Tumors of the Jaws. Journal of Oral and Maxillofacial Surgery, 65, 2018-2024.

[29] Balke, M. (2013) Denosumab Treatment of Giant Cell Tumour of Bone. The Lancet Oncology, 14, 801-802. http://dx.doi.org/10.1016/S1470-2045(13)70291-2

[30] Balke, M. and Hardes, J. (2010) Denosumab: A Breakthrough in Treatment of Giant-Cell Tumour of Bone? The Lancet Oncology, 11, 218-219. http://dx.doi.org/10.1016/S1470-2045(10)70027-9

[31] Purohit, S. and Pardiwala, D.N. (2007) Imaging of Giant Cell Tumor of Bone. The Indian Journal of Orthopaedics, 41, 91-96.

[32] Campanacci, M., Baldini, N., Boriani, S. and Sudanese, A. (1987) Giant-Cell Tumor of Bone. The Journal of Bone and Joint Surgery (American Volume), 69, 106-114.

[33] Mjöberg, B., Pettersson, H., Rosenqvist, R. and Rydholm, A. (1984) Bone Cement, Thermal Injury and the Radiolucent Zone. Acta Orthopaedica, 55, 597-600. http://dx.doi.org/10.3109/17453678408992403

[34] Pettersson, H., Rydholm, A. and Persson, B. (1986) Early Radiologic Detection of Local Recurrence after Curettage and Acrylic Cementation of Giant Cell Tumours. European Journal of Radiology, 6, 1-4.

[35] Remedios, D., Saifuddin, A. and Pringle, J. (1997) Radiological and Clinical Recurrence of Giant-Cell Tumour of Bone after the Use of Cement. The Journal of Bone and Joint Surgery (British Volume), 79-B, 26-30.

[36] Lee, F.Y., Chang, S.S., Suratwala, S.J., Jung, K.M., Doppelt, J.D., Zhang, H.Z., Blaine, T.A., Kim, T.W. and Winchester, R.J. (2004) Bisphosphonates May Reduce Recurrence in Giant Cell Tumor by Inducing Apoptosis. Clinical Orthopaedics and Related Research, 426, 103-109.

[37] Cooper, K.L., Beabout, J.W. and Dahlin, D.C. (1984) Giant Cell Tumor: Ossification in Soft-Tissue Implants. Radiology, 153, 597-602.

[38] Lee, M.J., Sallomi, D.F., Munk, P.L., Janzen, D.L., Connell, D.G., O’Connell, J.X., Logan, P.M. and Masri, B.A. (1998) Pictorial Review: Giant Cell Tumours of Bone. Clinical Radiology, 53, 481-489. 
http://dx.doi.org/10.1016/S0009-9260(98)80166-9

[39] Plosker, G.L. and Goa, K.L. (1994) Clodronate. A Review of Its Pharmacological Properties and Therapeutic Efficacy in Resorptive Bone Disease. Drugs, 47, 945-982. http://dx.doi.org/10.2165/00003495-199447060-00007

[40] Adami, S. and Zamberlan, N. (1996) Adverse Effects of Bisphosphonates. A Comparative Review. Drug Safety, 14, 158-170. http://dx.doi.org/10.2165/00002018-199614030-00003

[41] Markowitz, G.S., Appel, G.B., Fine, P.L., Fenves, A.Z., Loon, N.R., Jagannath, S., Kuhn, J.A., Dratch, A.D. and D’Agati, V.D. (2001) Collapsing Focal Segmental Glomerulosclerosis Following Treatment with High-Dose Pamidronate. Journal of the American Society of Nephrology, 12, 1164-1172.

[42] Hortobagyi, G.N., Theriault, R.L., Lipton, A., Porter, L., Blayney, D., Sinoff, C., Wheeler, H., Simeone, J.F., Seaman, J.J., Knight, R.D., Heffernan, M., Mellars, K. and Reitsma, D.J. (1998) Long-Term Prevention of Skeletal Complications of Metastatic Breast Cancer with Pamidronate. Protocol 19 Aredia Breast Cancer Study Group. Journal of Clinical Oncology, 16, 2038-2044.

[43] Liberman, U.I. and Hirsch, L.J. (1996) Esophagitis and Alendronate. The New England Journal of Medicine, 335, 1069-1070. http://dx.doi.org/10.1056/NEJM199610033351416

[44] Watts, N., Freedholm, D. and Daifotis, A. (1999) The Clinical Tolerability Profile of Alendronate. International Journal of Clinical Practice (Supplement), 101, 51-61.

[45] Marshall, J.K. (2002) The Gastrointestinal Tolerability and Safety of Oral Bisphosphonates. Expert Opinion on Drug Safety, 1, 71-78. http://dx.doi.org/10.1517/14740338.1.1.71

[46] Diel, I.J., Bergner, R. and Grötz, K.A. (2007) Adverse Effects of Bisphosphonates: Current Issues. The Journal of Supportive Oncology, 5, 475-482.

[47] Marx, R.E. (2003) Pamidronate (Aredia) and Zoledronate (Zometa) Induced Avascular Necrosis of the Jaws: A Growing Epidemic. Journal of Oral and Maxillofacial Surgery, 61, 1115-1117.

[48] Bamias, A., Kastritis, E., Bamia, C., Moulopoulos, L.A., Melakopoulos, I., Bozas, G., Koutsoukou, V., Gika, D., Anagnostopoulos, A., Papadimitriou, C., Terpos, E. and Dimopoulos, M.A. (2005) Osteonecrosis of the Jaw in Cancer after Treatment with Bisphosphonates: Incidence and Risk Factors. Journal of Clinical Oncology, 23, 8580-8587. http://dx.doi.org/10.1200/JCO.2005.02.8670

[49] Cummings, S.R., et al. (2009) Denosumab for Prevention of Fractures in Postmenopausal Women with Osteoporosis. The New England Journal of Medicine, 361, 756-765. http://dx.doi.org/10.1056/NEJMoa0809493

[50] Bone, H.G., et al. (2008) Effects of Denosumab on Bone Mineral Density and Bone Turnover in Postmenopausal Women. The Journal of Clinical Endocrinology and Metabolism, 93, 2149-2157. http://dx.doi.org/10.1210/jc.2007-2814

[51] Brown, J.P., et al. (2009) Comparison of the Effect of Denosumab and Alendronate on BMD and Biochemical Markers of Bone Turnover in Postmenopausal Women with Low bone Mass: A Randomized, Blinded, Phase 3 Trial. Journal of Bone and Mineral Research, 24, 153-161. http://dx.doi.org/10.1359/jbmr.0809010

[52] Kendler, D.L., et al. (2010) Effects of Denosumab on Bone Mineral Density and Bone Turnover in Postmenopausal Women Transitioning from Alendronate Therapy. Journal of Bone and Mineral Research, 25, 72-81. http://dx.doi.org/10.1359/jbmr.090716

[53] FDA Approves Xgeva for GCTB. http://www.fda.gov/Drugs/InformationOnDrugs/ApprovedDrugs/ucm356667.htm 